\title{
Suicide Attempt in a Patient with Sibutramine Associated \\ Psychosis
}

\section{Tentativa de Suicídio em Doente com Psicose Associada a Sibutramina}

\author{
Pedro CÂMARA PESTANA* $\rrbracket^{1,2}$, Carla FERREIRA*1,2, Ana Luísa SANTOS ${ }^{1}$, Joana JERÓNIMO ${ }^{1,2}$, Licínia GANANÇA ${ }^{1,2}$ \\ Acta Med Port 2022 Mar;35(3):216-218 - https://doi.org/10.20344/amp.14304
}

\begin{abstract}
Sibutramine is a serotonin-norepinephrine-dopamine reuptake inhibitor, initially developed as a potential antidepressant and later approved for the management of obesity. Sibutramine use is also associated with psychiatric symptoms, namely mania, panic attacks, and, less frequently, psychosis. We report the case of a 32-year-old man, admitted to our hospital due to a suicide attempt in the context of sibutramine-associated psychosis. The symptoms remitted completely after discontinuation of sibutramine and a brief period of antipsychotic medication. The aim of this manuscript is to highlight the importance of the recognition of sibutramine-associated psychosis, to discuss the possible pathophysiology and the proper clinical and therapeutic management.
\end{abstract}

Keywords: Liaison Psychiatry; Psychotic Disorders; Sibutramine; Suicide

\section{RESUMO}

A sibutramina é um inibidor não seletivo da recaptação de serotonina-noradrenalina-dopamina, inicialmente desenvolvido como potencial antidepressivo e posteriormente aprovado para o tratamento da obesidade. O uso de sibutramina está também associado ao aparecimento de sintomas psiquiátricos como mania, ataques de pânico e, com menor frequência, psicose. Relatamos um caso de um homem de 32 anos, internado no nosso hospital devido a uma tentativa de suicídio no contexto de uma psicose associada à sibutramina. Os sintomas remitiram completamente após a descontinuação da sibutramina e um breve período de terapêutica antipsicótica. O objetivo deste artigo é destacar a importância do reconhecimento da psicose associada à sibutramina, discutir a sua possível fisiopatologia e o seu apropriado manejo clínico e terapêutico.

Palavras-chave: Perturbações Psicóticas; Psiquiatria de Ligação; Sibutramina; Suicídio

\section{INTRODUCTION}

Sibutramine, a serotonin-norepinephrine-dopamine reuptake inhibitor, was approved by the Food and Drug Administration (FDA) in November 1997 for weight loss and maintenance of weight loss in patients with a body mass index (BMI) greater than or equal to $30(\geq 30) \mathrm{kg} / \mathrm{m}^{2}$ or for patients with a BMI over $27 \mathrm{~kg} / \mathrm{m}^{2}$ with other cardiovascular risk factors, after being initially developed as a potential antidepressant. ${ }^{1}$ Despite the marketing ban issued by the European Medicines Agency in 2010, due to cardiovascular safety concerns, its use remains common, although illegal, as an anti-obesity medication. Sibutramine can be bought in the black market, usually as a hidden ingredient of some illegal weight-loss products. Sibutramine use is also associated with psychiatric symptoms, namely mania, panic attacks, and, less frequently, psychosis, ${ }^{2-5}$ but the real incidence and frequency of these clinical features is difficult to determine because there is no reliable data on its consumption worldwide.

We report a case of suicide attempt in the context of sibutramine-associated psychosis, to highlight the importance of the recognition of this condition and to discuss the possible pathophysiology as well as the proper clinical and therapeutic management.

\section{CASE REPORT}

A 32-year-old single man from Brazil, working in Portugal as an elderly caregiver, with no personal history of previous psychiatric or neurological disorders, and with a family history of depressive disorder (namely his mother and a maternal aunt) was admitted to the emergency department due to a suicide attempt where the patient jumped from a $4^{\text {th }}$-floor window in December 2019. He was initially evaluated by orthopedic surgery, which documented several fractures. His mental status examination revealed perplexity, hyperprosexia (excessive fixity of attention on a stimulus object), anxious mood, behavior indicative of auditory hallucinations, kinesthetic hallucinations, suicide ideation and loss of self-boundaries (the loss of the awareness of the separation between the individual and the environment). Drug scan for amphetamines, cannabis, cocaine and opiates was negative. The patient was then admitted to the orthopedic surgery ward. Besides analgesic drugs, the patient was prescribed olanzapine $10 \mathrm{mg} /$ day. One month following admission, after undergoing major surgical procedures, the patient was reassessed by liaison psychiatry and liaison psychology. The psychotic symptoms and suicide ideation had remitted. The patient disclosed that, since the age of 18 , due to being overweight, he had been self-medicating with $15 \mathrm{mg}$ sibutramine for 2-month length cycles. In the

\footnotetext{
* Co-first authors.

1. Department of Psychiatry and Mental Health. Hospital de Santa Maria. Centro Hospitalar Lisboa Norte. Lisboa. Portugal.

2. Department of Psychiatry. Faculty of Medicine. University of Lisbon. Lisboa. Portugal.

$\triangle$ Autor correspondente: Pedro Câmara Pestana. p.camarapestana@gmail.com

Recebido: 09 de junho de 2020 - Aceite: 24 de julho de 2020 - First published: 04 de maio de 2021 - Online issue published: 02 de março de 2022 Copyright $\odot$ Ordem dos Médicos 2022
} 
first of these cycles, at age 18, no associated psychiatric symptoms were reported. The second cycle, when the patient was 21, was associated with overvalued ideas of reference, suspiciousness, sadness, and a feeling of abandonment, and these symptoms were self-limited to the duration of the sibutramine cycle. Between the age of 22 and 32 , the patient reported completing one to two cycles of 15 mg sibutramine per year, and all were associated with the same aforementioned symptoms. Eight months before admission, the patient reported a period of overwork, with an increased volume of night shifts and a subsequent inversion of his sleep-wake cycle. During that period, and in the three months before admission, he took a $15 \mathrm{mg}$ sibutramine onemonth cycle, followed by a $30 \mathrm{mg}$ two-months cycle with the sibutramine pills that he had brought from Brazil. The patient reported the progressive appearance of overvalued ideas of guilt, reference, elementary auditory hallucinations, somatic anxiety, and mixed insomnia. These symptoms evolved to delusional reference and persecutory ideas, complex auditory hallucinations, accompanied by suicide ideation in early December 2019. Due to these symptoms, the patient abruptly stopped sibutramine a week before the hospital admission. However, the symptoms remained present, and the patient attributed his suicide attempt, a defenestration from his bedroom window to an impulsive, unplanned and desperate act to stop his suffering. Three months after admission, the patient was discharged without any psychotic symptoms, medicated with olanzapine $10 \mathrm{mg} / \mathrm{day}$, and referred to both orthopedic surgery and psychiatric follow-up appointments.

\section{DISCUSSION}

There are few reported cases of sibutramine induced psychosis in the literature, and hence the importance of disclosing such clinical cases, in order to promote a better understanding of its clinical features. Clinically, the psychiatric symptoms of our patient are in line with the few reported cases of sibutramine associated psychosis: a case series of 16 patients with sibutramine associated psychosis revealed auditory hallucination in $(63 \%)$, persecutory ideas $(38 \%)$, delusions (25\%), and suicidal ideation $(13 \%){ }^{6}$

Initial reports regarding the receptor-binding properties of sibutramine and its metabolites underestimate the dopaminergic reuptake inhibition of sibutramine compared with the reuptake inhibition of serotonin and noradrenaline. However, more recently, some animal studies suggested a dose-related dopaminergic reuptake inhibition in both the striatal and hypothalamic regions. ${ }^{2}$ This finding may explain, at least partially, not only the relationship between sibutramine and psychosis, ${ }^{7}$ according with the most accepted dopaminergic theory of psychosis, but also, the fact that our patient only developed psychotic symptoms and suicide ideation under a sibutramine $30 \mathrm{mg}$ cycle and not with the previous $15 \mathrm{mg}$ cycles. Furthermore, using the algorithm of Naranjo et $a l^{\beta}$ to estimate the probability of an adverse drug reaction, this case report would obtain a probable score of 7 points.
Regarding the delay between sibutramine intake and the onset of psychotic symptoms observed in our patient, some authors argue that it might be the result of a reverse tolerance phenomenon that is similar to the phenomenon described for cocaine and amphetamine abuse, or that sibutramine may act as a precipitating factor in psychosispredisposed patients. $^{9}$

In terms of the psychopharmacological approach, as in other case reports, ${ }^{2}$ the symptoms remitted completely after sibutramine discontinuation and a brief period of antipsychotic medication.

Regarding limitations, we recognize that the absence of a collateral source of information, namely, a close relative, and the fact that the mental state examination had taken place in a liaison psychiatry setting may have limited the accuracy of some clinical elements. However, we tried to mitigate such facts by interviewing the patient in different moments in order to better characterize this case report.

\section{CONCLUSION}

Sibutramine may act as a risk factor for psychosis in predisposed patients. Suspension of sibutramine intake and treatment with a low dose antipsychotic, for a short period, appears to be effective in symptom remission. If, in a suspected case of sibutramine induced psychosis, the symptoms persist after those measures are taken, then the case must be reassessed, and another differential diagnosis should be considered. Further studies are required to elucidate the relationship between sibutramine and psychosis and the underlying pathophysiology.

\section{AUTHORS CONTRIBUTION}

PCP, CF: Substantial contribution for the draft of the manuscript. Clinical follow-up of the patient and case review.

ALS, JJ, LG: Substantial intellectual contribution. Case review and critical review of the paper.

\section{PROTECTION OF HUMANS AND ANIMALS}

The authors declare that the procedures were followed according to the regulations established by the Clinical Research and Ethics Committee and to the Helsinki Declaration of the World Medical Association updated in 2013.

\section{DATA CONFIDENTIALITY}

The authors declare having followed the protocols in use at their working center regarding patients' data publication.

\section{PATIENT CONSENT}

The authors received consent from the patient to publish the report and the information has been de-identified to protect anonymity.

\section{COMPETING INTERESTS}

The authors have declared that no competing interests exist. 


\section{FUNDING SOURCES}

No subsidies or grants contributed to this work.

\section{REFERENCES}

1. Luque CA, Rey JA. Sibutramine: a serotonin-norepinephrine reuptakeinhibitor for the treatment of obesity. Ann Pharmacother. 1999;33:96878.

2. Lee J, Teoh T, Lee TS. Catatonia and psychosis associated with sibutramine: a case report and pathophysiologic correlation. J Psychosom Res. 2008;64:107-9.

3. Binkley K, Knowles S. Sibutramine and panic attacks. Am J Psychiatry. 2002;159:1793-4.

4. Cordeiro $\mathrm{Q}$, Vallada $\mathrm{H}$. Sibutramine-induced mania episode in a bipolar patient. Int J Neuropsychopharmacol. 2002;5:283-4.

5. Waszkiewicz N, Zalewska-Szajda B, Szajda S, Simonienko K, Zalewska A, Szulc A, et al. Sibutramine-induced mania as the first manifestation of bipolar disorder. BMC Psychiatry. 2012;12:43.

6. Chen S, Tang M, Ng S, Poon W, Chan A, Mak T. Psychosis associated with usage of herbal slimming products adulterated with sibutramine: a case series. Clin Toxicol. 2010;48:832-8.

7. Rosenbohm A, Bux C, Connemann B. Psychosis with sibutramine. J Clin Psychopharmacol. 2007;27:315-7.

8. Naranjo C, Busto U, Sellers E, Sandor P, Ruiz I, Roberts E, et al. A method for estimating the probability of adverse drug reactions. Clin Pharmacol Ther. 1981;30:239-45.

9. Litvan L, Alcoverro-Fortuny O. Sibutramine and psychosis. J Clin Psychopharmacol. 2007;27:726-7. 